\title{
Faculty Members' Attitudes Towards Using Moodle at Palestine Technical Khadoorie (PTUK)
}

\author{
Reham A. Salhab ${ }^{1, *}$ \\ ${ }^{1}$ Technology Education Department, Palestine Technical University Khadoorie (PTUK), Tulkarem, Palsetine \\ *Correspondence: Technology Education Department, Palestine Technical University Khadoorie (PTUK), Tulkarem, \\ Palsetine. E-mail: r.salhab@ptuk.edu.ps
}

Received: March 4, 2019 Accepted: April 4, $2019 \quad$ Online Published: April 20, 2019

doi:10.5430/wje.v9n2p151 URL: https://doi.org/10.5430/wje.v9n2p151

\begin{abstract}
Digital education reshaped the teaching and learning processes in higher education worldwide. This study investigates the attitudes of faculty members at Palestine Technical Khadoorie University (PTUK) towards using Modular Object Oriented Dynamic Learning Environment (MOODLE). A questionnaire was designed to conduct the present study at PTUK. A convenient sample of 41participants from two different colleges, Applied Science and Humanities colleges contributed in this study. Findings revealed that faculty members at PTUK had positive attitudes towards Moodle. Nevertheless, there was a significant difference between faculty member attitudes with regard to no. of training sessions offered by PTUK.
\end{abstract}

Keywords: digital education, Moodle, PTUK, teaching, learning

\section{Introduction}

In response to the interaction between of innovative technologies and traditional teaching, learning shifted from traditional face-to-face models to blended interactive learning environments which provides instructor with a valuable opportunity to improve their teaching methods, to assess student learning, and enhances learning community. Instructors consider augmenting traditional methods of teaching with tasks and different methods of assessment that take advantage of the online environment's great flexibility and its new capabilities and strengths (Pachler \& Daly, 2011). Digital education aims to create an interactive environment rich in applications based on computer technology and the Internet, and enables students to access their learning resources timely and anywhere. Digital education defined as providing educational content with its explanatory notes, exercises and interaction and follow-up partially or comprehensively in the classroom or remotely through programs or stored on computers or through the Internet (Carnell \& Fung 2017). Hamed (2019) also defined digital education as educational system that uses information technology and computer networks to strengthen and expand the educational process through a variety of means, including computer, Internet and electronic programs prepared by specialists in academic institutions or companies. So, digital teaching works to provide education through advanced technological methods such as:

Internet, CDs, cassettes, videos, DVDs, Cell phones, PDAs, electronic notebooks

The term "digital learning" is used to describe a range of learning situations, including

Electronic learning, web learning, virtual classroom classes and more (Hamed, 2019).

Electronic Learning ( e-learning) also called virtual learning Environments (VLE)has been recently adopted by many higher education institutions since it offered meaningful and active learning that put more emphasis on how to learn and to think in multiple ways (Brown, Dehoney, \& Millichap, 2015). E-Learning is an instructional process that traditionally uses a computer and internet in which includes content, media elements, forums, exams, chartrooms, and videoconferences (Bates \& Sangrà, 2011).

The e- learning process has introduced new and unambiguous teaching methods by connecting groups of learners by video streaming, chartrooms, and discussion boards (Black, Beck, Dawson, Jinks, \& DiPietro, 2007). The E-Learning network is highly spreadable as a result of technological development, so universities started offering 
courses through network, including regular attendance ones. This pattern has prompted several universities around the world to introduce several programs for regular courses. This type of learning increases students' capacities and performance and widens their knowledge base (Tinmaz, 2012).

E-learning has introduced innovations in recent learning and teaching methods, as it has invested the latest and modern techniques in learning processes (Breen \& Paul, 2018). E-learning provides learners with various and multiple skills and learning experiences. Learning electronically, combines several ways to achieve maximum productivity (Ozkan \& Koseler, 2009).

Blended Learning is a form of e-learning, as learners canaccess the university's academic portal and from there to the course site assigned by the campus (Horton, 2011). The course site includes questions that should be answered after or before the lectures and learners can follow variety of responses. This process will improve the ability to generate many different and new ideas, and thus develophigher intellectual skills such as creative thinking, critical thinking, and other cognitive skills. In addition, learners interact witheach others. Blended learning should be imposed by a pedagogical model to promote active learning, otherwise negative results might happen (Jacob, Wilson, \& Baker, 2015).

Learning management system (LMS) is an integral part of e learning courses, whether it isblended format, online format or web facilitated format (Masadeh \& Elfeky, 2016). Some of the examples of these systems are: Sakai; Jenzabar; eCollege; Blackboard; Moodle; Webtrain (Santos, Inan, \& Denton, 2012). The user of these systems notes that all of them are based on the principle of interaction between the elements of the educational process by implementing multimedia explaining the curriculum ,texts, group forums, individual and collaborative projects. Regrettably, not all LMSs are basically used as a tool for interaction, rather it is used information dissemination (Kvavik \& Caruso, 2005, Piotrowski, 2010).

A considerable amount of research has been done recently that showed teachers acceptance of digital technology in the classroom(Inan \& Lowther, 2010, Perrotta, 2013) These studies focused at three variables of teachers acceptance, personal beliefs, ict infrastructure and teachers' skills to use digital technology.)

Badia, 2014 focused on Moodle which is web-based platform in the academic institution of a group of instructors and student spursuing a bachelor degree at a university in Palestine. Moodle is an open source Course Management System (CMS) that allows educators to create an online environment in support of teaching and learning activities. Within CMSs are features such as file uploads, discussion forums, assignment submission functions, calendar entries and grading options. One commonality shared by CMSs is that they are organized in a course-based mode, and linked with course enrollment.

\subsection{Significance of the Study}

Palestine Technical University-Khadoori (PTUK) had fostered Moodle since 2011 and decided to use and extend an existing e- learning platform to support lessons offered at PTUK, to encourage faculty instructors to develop their lessons online that will be delivered synchronously and asynchronously to be implemented in their traditional lessons. This study goal is to investigate the attitudes of PTUK faculty members since it is still a new experience for them.

Many instructors still don't know what is blended learning or even what some of the terms used to describe it, others may have a notion of what's involved, but feel some trepidation about handling the issues they may encounter. In this study the results of questionnaire are presented in order to reflect the attitudes of instructors toward Moodle and consequently the impact of implementing LMS in everyday teaching practice on the academicexperience. Participation in the study was anonymous faculty members.

\subsection{Statement of the Problem and the Study's Questions}

The study aimed to assess the attitudes of using Modular Object Oriented Dynamic Learning Environment on faculty members of Science and Arts students' and lecturers' at PTUK. The results of this study should be of interest to PTUK as most faculty members teach courses via Moodle platform. In addition, it can help many universities that are still reluctant to decide the extent of their offerings of online or blended courses. This study aimed to identify the answer of the following questions:

Q1. What are the attitudes of faculty members in Applied Sciences and Humanities towards using Moodle in the teaching and learning processes.

Q2: Is there any statistically significant difference between faculty members' attitudes which can be attributed to academic degree, gender, years of experience, age, college classification, no. of classes being taught by Moodle, and no. training sessions. 


\section{Literature Review}

A relatively fair number of papers had been published on faculty members' and students' attitudes towards LMS platforms in Palestinian universities. Moodle is one of these platforms, that are most popular used among Palestinian universities since 2011. Carnell \& Fung (2017) reported that about $85 \%$ of faculty members use Moodle and $74 \%$ of them note that it improves teaching and learning. On the other hand, Carnell and Fung (2017) showed that the institution should train its faculty members to use advanced features in Moodle.

Most e-learning platforms provide tools such as forums, emails, blogs, walls (asynchronous tools), discussion rooms (synchronous tools), wikis, glossaries, texts, and online surveys (collective construction and interactive tools). They also include educational activities, books, videos, audio, files (educational tools); profile, registration, groups, databases, frequency control and daily classes (administrative tools) (Badia, Martín, \& Gómez, 2018). In this context, Moodle (Modular Object Oriented Dynamic Learning Environment) tool is defined as a platform built from a constructivist perspective that emphasizes on research and collaboration through its structure and available features developed for training (Martín-Blas, \& Serrano-Fernández, 2009). The training features include both communication (chats, forums, wikis, blogs, glossaries, quizzes) and information (textual data, audio, images, video links, and search tools).

Moodle can be usedin e -learning tool and blended learning tool (a combination offace to face and online). Most academic institutions are using blended learning as it offers more space and time. A computer scientist MartinDougiamasfrom Perth University in Australia, created Moodlewhere he began to think of this system when all learning management systems were found to be expensive and were designed by engineers who lack an educational and pedagogical backgrounds. So he found it necessary to employ his educational and technical expertise in the design of an open source learning management system available for any individual use for free (http://moodle.org, 2019).

Dougiamas adoptedtheSocialconstructive theory which was based on the idea that favors learners learn better when they engage in social processes to build knowledge. The difference between the philosophy of the traditional class and the philosophy of social constructivism is as a difference between lectures and discussions. The term refers to a social process that occursbetween groupswhile learning.

Moodle was created basedondiscussion between learners and active participation and knowledgeamong them. Teacherswho implementMoodle in their teaching, do not require the use of social constructivism in the construction of the course, whichMoodle supports it already. Moodle offers the choice of course material that the student can read, see and, but cannot interact with: text pages, webpages, images, educational movies, hyperlinks, educational folders (Franco, 2010). Moreover, it can also add patterns of interactive course material such as: group chat, forums, individual and group projects, surveys on a particular subject, etc. These materials enable students to collaborate and share among themselves and their teachers to build and learn content. (Carvalho, Da Silva, \& Freitag, 2013; Sanchez \& Hureos, 2010; Lane, 2009)

Moodle is considered to be a program thatassists in the development of an electronic learning environment provided through tools and features to implement needed tasks in this direction, such as: a tool used to build the electronic curriculum (gathering-sorting-display) in a organized way. In addition to, it can only be used to a certain users that defined by the teacher or an academic institution, Moodle could be used as method of connection between the site that displays the educational material and its beneficiaries, and a tool that provides users with the educational site with many periodic information when they access the tools (Nordin \& Ibrahim, 2012). Moodle is also viewed as a software package that allows the teacher to download the material he or she teaches on a website, allows learners to communicate and interact with each other and communicate with their teachers (Carvalho et al., 2013; Lane, 2009; Nordin et al., 2012).

Moodle software has several advantages, including:

1. Easiness: Moodle software allows users to communicate and interact with the instructional material by connecting to the Internet at any time and from anywhere. Students can review the course material, lectures, assignments and any other audio-visual aids. They can also send their assignments and projects to their teacher as soon as they complete them (Park \& Mills, 2014).

2. Provide instant feedback: The program provides instant feedback feed on the results of the tests and the student's interest from the teacher or his colleagues through the discussion board, or e-mail, etc., and provide feedback about the student's program and its benefits. Communication 3 Improving and facilitating process: The software has several characteristics that allow students to communicate with their teachers (Ngampornchai \& Adams, 2016) 
3.Improving and facilitatinglearningprocess: Moodle has several characteristics that allow students to communicate with their teachers and with their colleagues, through several options provided by the software such as announcements, discussions, categorical classes, e-mail and others. Moodle facilitates administrative work on teachersand the educational institution. As for the discussion forum, it helps teachers to share notes, comments, syllabus, opinions and link toprovide their students with additional support by encouraging them to respond to the questions and interact with their colleagues (Sallam \& Alzouebi, 2014)

4. Moodle software tracks students' use of this software and records results in a statistical file during the learning period which helps teachers in the assessment process. Also teachers can obtain statistical information about all studentsprogress which helpsinstructors to track students participation andtheir individual assignments, date and time assignments sent by students that will help students to pursue their own progress (William, 2015).

5. Skills building: there are several additional skills in Moodle to help the student to do their tasks efficiently like organization and time management to help students to use time wisely. In addition, Moodle helps the teacher to pay attention to the learning patterns of their students, to help him teach, to download the material and the necessary activities, exercises, tasks and tests, using multimedia (writing, stationary, motion pictures, etc.) For example students who depends on listening and pronunciation and which favors words, language, written and spoken phrases, can be easily met; moreover and look at things from multiple angles so as to benefit from the discussion board in the software, as it allows the learner to search for many topics, the software meets the needs of the visual learner, which learns through the presentation ,charts, films, and films; in addition to meeting the needs of the learner who prefers to learn by doing work, that is, who enjoys learning through simulations, role plays, creative movements, and work (Park \& Mills, 2014, William, 2015, Masadeh \& Elfeky, 2015).

Carvalho et al. (2013) indicated that Moodle software promotesthe principles of effective learning by thefollowings:

1. An increased interaction and flexibility learning environments, based on the guidance of the teacher, and instructions and regulations of the educational institution on the process of communication, delivery of assignments, and tests using the digital transmission box, or e-mail in the teacher's special software, it builds confidence among students themselves (Franco, 2010).

2. Moodle allows teachersto share educational material, syllabus, opinions and online assignments with their studentsto moderate and facilitate student's learning. Also, teachers can use Moodle software to send an e-mail to one student or to a group of student.

3. Helps learnersto develop multiple talents by allowing them to choose their own project, discuss withtheir colleagues, and work collaboratively. This allows learners to search topics that suit their interests and needs, participate in discussions by asking questions or answering questions posed by colleagues.

Fadel, Elbilgahy, Ibrahim \& Elmashad (2019) investigated lecturers' at Faculty ofNursing, Mansoura University attitudes towards Moodle. A quasi experiment designwas performed. A sample of 30 nursing lecturers participated used; a structured questionnaire was distributed to the nursing lecturers.Reults showed that nursinglecturers had positive attitudes towards Moodle afterimplementing Moodle intheir courses.

Further more, Caliskana \& Bicena (2016) conducted a study to investigate the perceptions of teacher candidates towards Moodle incertain learning environments b.A sample of 120 teachers from Near East University participated in the study. A questionnaire was used as a study tool. Resultsshowed thatteachers were excited and had positive experience by using Moodle learning system.

\section{The Study's Methodology}

Data in this study was collected through a questionnaire; the researcher adopted a descriptive approach. Through this approach, data was collected, analyzed, organized and interpreted.

\subsection{The Study's Instrument}

This study involved a questionnaire as a study's instrument which was developed by the researcher. This questionnaire aims to identify the attitudes of faculty members towards Moodle in. It consists from 31 statements. These statements address two types.

The researcher developed a questionnaire for the study of the attitudes of academic faculty members towards the use of the Moodle system in the teaching and learning processes at Khadouri University. The study tool included two main parts: 
First: Personal data relating to the academic qualification, gender, age, years of experience, college classification, number of courses to use Moodleand no. of training sessions of Moodle

Second: This part consisted of 31 paragraphs.

\subsection{The Study's Sample}

The study's population involves all faculty members who work at Applied Science and Science faculty and Arts and Educational Sciences faculty at Palestine Technical Khadoorie University (PTUK) (i.e 73 faculty members). A convenient sample of 41 faculty members who work at Applied Science faculty and Arts and Educational Sciences faculty at PTUK participated in this study during the fall semester of academic year 2018/2019. Those members were selected through using the random stratified method. Table (1) describes the characteristics of the sample. The questions divided in 5 groups, the first group contains7 questions including gender, academic degree, years of experience, age, faculty type, number of course being taught by Moodle numbers of training sessions for Moodle. The researcher used these questions as external factors to examine if they affect their attitudes towards the system. The second group contains 31 questions divided to 6 groups, 11 questions for Moodle facilitation and organizing learning and teaching processes, 7 questions for enhancing teaching methods, 4 question for improving assessment process, 2 questions for effective communication, 7 questions for technical difficulties. A 5-point Likert scale (strongly agree, agree, neutral, disagree, and strongly disagree) was used in the second group to measure faculty responses.

\subsection{Reliability and Validity of the Study Instrument}

Reliability and validity of the items in the questionnaire were measured. Reliability was measured by calculating coefficient using the equation Cronbach's Alpha of 0.895 on all paragraphs of the questionnaire which is suitable for statistical analysis and for the purposes of study. The researchers checked the questionnaire's validity. That was done through passing the questionnaire to 9 educational experts who work at different Palestinian universities.

\subsection{Study' Design}

The researcher used the descriptive approach method to study the relationship between the variables of the study and the collection of information and the use of statistical analysis to examine the hypotheses in order to interpret the results. The study included the following variables:

Independent variables:

1- Academic degree with three levels

2 - Gender variable and has two levels.

3- Age with four levels

4. Years experience and has three levels.

5 - Number of courses and has five items

6 - Training sessions courses has three items

7- College classification and has two items

The following variables were included in the responses to the questionnaires related to the study of the attitudes of academic faculty members towards the use of Moodle in the teaching and learning processes at Palestine Technical University Khadoorie (PTUK). To process the data, the SPSS program was used by using the following treatments:

- Frequency and Percent

- Averages, Means, SD

- T- test for one sample

- T- test for two independent samples

- ANOVA

- Cronbach Alpha to calculate the coefficient of Reliability 
Table 1. The Characteristics of the Sample

\begin{tabular}{|c|c|c|c|}
\hline Variable & characteristics & frequency & Percent \\
\hline \multirow[t]{4}{*}{ Academic degree } & Bachelor & 12 & 29.3 \\
\hline & Master & 15 & 36.6 \\
\hline & Doctorate & 14 & 34.1 \\
\hline & total & 41 & 100.0 \\
\hline \multirow[t]{3}{*}{ Gender } & male & 21 & 51.2 \\
\hline & female & 20 & 48.8 \\
\hline & Total & 41 & 100.0 \\
\hline \multirow[t]{4}{*}{ Age } & $35-25$ & 21 & 51.2 \\
\hline & $45-36$ & 6 & 14.6 \\
\hline & $55-46$ & 14 & 34.1 \\
\hline & total & 41 & 100.0 \\
\hline \multirow[t]{4}{*}{ Teaching Experience } & $<5$ & 24 & 58.5 \\
\hline & $6-10$ & 3 & 7.3 \\
\hline & $>11$ & 14 & 34.1 \\
\hline & total & 41 & 100.0 \\
\hline \multirow{6}{*}{$\begin{array}{l}\text { No. of coursesbeing taught } \\
\text { by Moodle }\end{array}$} & One course & 7 & 17.1 \\
\hline & Two courses & 7 & 17.1 \\
\hline & Three courses & 10 & 24.4 \\
\hline & Four courses & 8 & 19.5 \\
\hline & Five courses & 9 & 22.0 \\
\hline & total & 41 & 100.0 \\
\hline \multirow[t]{4}{*}{ No. of training sessions } & none & 31 & 75.6 \\
\hline & $>1$ & 4 & 9.8 \\
\hline & $>3$ & 6 & 14.6 \\
\hline & total & 41 & 100.0 \\
\hline \multirow{3}{*}{ College classification } & Applied Sciences & 32 & 78.0 \\
\hline & Arts and Educational Sciences & 9 & 22.0 \\
\hline & total & 41 & 100.0 \\
\hline Variable & characteristics & frequency & Percent \\
\hline \multirow[t]{4}{*}{ Academic degree } & Bachelor & 12 & 29.3 \\
\hline & Master & 15 & 36.6 \\
\hline & Doctorate & 14 & 34.1 \\
\hline & total & 41 & 100.0 \\
\hline \multirow[t]{3}{*}{ Gender } & male & 21 & 51.2 \\
\hline & female & 20 & 48.8 \\
\hline & Total & 41 & 100.0 \\
\hline \multirow[t]{4}{*}{ Age } & $35-25$ & 21 & 51.2 \\
\hline & $45-36$ & 6 & 14.6 \\
\hline & $55-46$ & 14 & 34.1 \\
\hline & total & 41 & 100.0 \\
\hline \multirow{4}{*}{ Teaching Experience } & $<5$ & 24 & 58.5 \\
\hline & $6-10$ & 3 & 7.3 \\
\hline & $>11$ & 14 & 34.1 \\
\hline & total & 41 & 100.0 \\
\hline \multirow{6}{*}{$\begin{array}{l}\text { No. of courses being taught } \\
\text { by Moodle }\end{array}$} & One course & 7 & 17.1 \\
\hline & Two courses & 7 & 17.1 \\
\hline & Three courses & 10 & 24.4 \\
\hline & Four courses & 8 & 19.5 \\
\hline & Five courses & 9 & 22.0 \\
\hline & total & 41 & 100.0 \\
\hline \multirow[t]{4}{*}{ No. of training sessions } & none & 31 & 75.6 \\
\hline & $>1$ & 4 & 9.8 \\
\hline & $>3$ & 6 & 14.6 \\
\hline & total & 41 & 100.0 \\
\hline \multirow[t]{3}{*}{ College classification } & Applied Sciences & 32 & 78.0 \\
\hline & Arts and Educational Sciences & 9 & 22.0 \\
\hline & total & 41 & 100.0 \\
\hline
\end{tabular}




\section{Results \& Study Analysis}

This section deals with answers to the questions of the study and its statistical examination on the program of statistical packages for social sciences (SPSS).

The first question of the study is what are the attitudes of Faculty members who teach at Applied Science and Humanities at PTUK towards using Moodle in teaching and learning processes. To answer this question, mean, standard deviations and percents were calculated. A single sample T-test and the results of tables (2-6) were used as follows:

Table 2. Results of the T- test for One Sample of the Field of the Academic Lecturers' Trend Scale Towards the Use of Moodle in the Teaching and Learning Processes at PTUK

\begin{tabular}{lccccccc}
\hline \multicolumn{1}{c}{ Field } & SD & Mean & Degree & order & Sig & T value & Percent \\
\hline $\begin{array}{l}\text { Facilitating and organizing of learning } \\
\text { teaching processes }\end{array}$ & 0.49568 & 3.5701 & High & 1 & .000 & 7.364 & 71.402 \\
Enhancing Teaching methods & & & & & & & \\
Assessment process improvement & 0.67438 & 3.4344 & High & 5 & .000 & 4.124 & 68.688 \\
Effective Communication process & 0.70824 & 3.5549 & High & 2 & .000 & 5.017 & 71.098 \\
Moodle technical Difficulties & 0.57037 & 3.4756 & High & 4 & .000 & 4.543 & 69.512 \\
Total construct & 0.47216 & 3.5122 & High & & .000 & 6.946 & 70.244 \\
\hline
\end{tabular}

The results of Table (2) show that the level of lecturers' attitudes towards using Moodle in the teaching and learning processes are of an average of 3.5122 and a relative percent of 70.244 with high agreement. The results also showed that the level of facilitation and organization of learning and teaching processes was 3.570 with 71.402 percent . The results of enhancing teaching methods were 3.4344 with 68.688 percent. The results showed that the effectiveness of communication process was 3.4756 and 69.512 percent. So, there are positive attitudes of the faculty members towards using Moodle in the learning teaching processes.

Table 3. Means, Standard Deviations, Percents and the T Value of the Sample Scores on the Field of Facilitation and Organization of learning and Teaching Processes

\begin{tabular}{lccccccc}
\hline Items & Means & Sig & T value & percent & S.D & Order & Agreement \\
\hline Moodle affects learning process positively & 4.0976 & .000 & 8.783 & 81.952 & 0.80015 & 2 & High \\
Moodle facilitates assignments posting & 4.1463 & .000 & 10.616 & 82.926 & 0.69141 & 1 & High \\
Moodle is a one more added task for the lecturers & 3.6098 & .000 & 4.250 & 72.196 & 0.91864 & 5 & High \\
Moodle improves student academic achievement & 3.2683 & .109 & 1.637 & 65.366 & 1.04939 & 9 & High \\
Technical Assistant is available frequently & 3.5122 & .002 & 3.270 & 70.244 & 1.00304 & 7 & High \\
$\begin{array}{l}\text { Moodle will replace traditional teaching } \\
\text { Moodle increases the cooperation between }\end{array}$ & 3.0244 & .891 & .138 & 60.488 & 1.12889 & 11 & High \\
institutes & 3.5366 & .000 & 4.612 & 70.732 & 0.7449 & 6 & High \\
$\begin{array}{l}\text { Moodle reinforce competition between } \\
\text { institutions }\end{array}$ & 3.4878 & .002 & 3.376 & 69.756 & 0.92526 & 8 & High \\
Moodle saves time when posting tasks & & & & & & & \\
Moodle offers deep learning & 3.8293 & .000 & 6.151 & 76.586 & 0.8632 & 3 & High \\
Moodle offers flexibility & 3.0732 & .637 & .476 & 61.464 & 0.98464 & 10 & Medium \\
Total & 3.675 & .000 & 5.152 & 73.5 & 0.82858 & 4 & High \\
\hline
\end{tabular}

The results of Table (3) indicate that the level of attitudes of faculty members towards the use of Moodle in the teaching learning process at Palestine Technical Khadoorie University (PTUK) on the facilitation and organization of learning teaching processes came at an average of 3.5701 and a relative weight of 71.402 . The process of posting homework and evaluation with an average of 4.4163 and a relative weight of 82.926, which is significantly high and paragraph amounted to 0.000 and this value is less than $\alpha=0.05$, while it was found that the lowest order was the sixth paragraph (Learning by Moodle Will replace traditional teaching) with a mean of 3.0244 and a 60.48 percent, a moderate with a significance of 0.891 and this value is greater than $\alpha=0.05$ which means faculty members did not agree that Moodle will replace traditional teaching one day. Moreover, faculty members disagree that Moodle offers deep learning. 
Table 4. Means, Standard Deviations, Percents and T Value of the Sample Scores on the Field of Teaching Methods Development

\begin{tabular}{|c|c|c|c|c|c|c|c|}
\hline Items & SD & Means & Agreement & Order & Sig & T-value & percent \\
\hline Learners care more when they use Moodle & 1.02529 & 3.2683 & High & 5 & .102 & 1.676 & 65.366 \\
\hline Moodle should be used in all subjects & 1.10911 & 3.525 & High & 4 & .005 & 2.994 & 70.5 \\
\hline Moodle improves teaching methods & 0.97718 & 3.5366 & High & 3 & .001 & 3.516 & 70.732 \\
\hline Moodle reinforces cooperation between students & 1.01092 & 3.6829 & High & 1 & .000 & 4.326 & 73.658 \\
\hline Modle enhances creative thinking & 1.01272 & 3.2195 & Mid & 6 & .173 & 1.388 & 64.39 \\
\hline Moodle enhances critical thinking & 1.06095 & 3.2195 & Mid & 6 & .193 & 1.325 & 64.39 \\
\hline Moodle gives feedback better than traditional & 0.89101 & 3.6098 & High & 2 & .000 & 4.382 & 72.196 \\
\hline Total & 0.67438 & 3.4344 & High & & .000 & 4.124 & 68.688 \\
\hline
\end{tabular}

The results of table (4) indicate that the level of attitudes of faculty members towards the use of Moodle in the learning teaching processes on the field of enhancing teaching methods came at an average of 3.4344 and a 68.688 percent . The results showed that the highest ranking of the fourth paragraph is that Moodle reinforces cooperation between students with an average of 3.6829 and a 73.658 percent. The level of significance calculated on this paragraph is 0.000 and this value is less than the specified level $\alpha=0.05$, while the lowest in the order was the fifth paragraph, Moodle enhances creative thinking of 3.2195 with a 64.39 percent and a0.173 significance which means that faculty members disagree that Moodle affects critical thinking. The sixth paragraph (Moodle enhances critical thinking among students) with an average of 3.2195 and a 64.39percent with a medium degree. This paragraph is also not significant because the significance level is higher than the $\alpha=0.05$.

Table 5. Mean, Standard Deviations, Percents and T Value of the Sample Scores on the Field of Assessment Process Improvement

\begin{tabular}{lccccccc}
\hline \multicolumn{1}{c}{ Item } & SD & Mean & Sig & T value & Percent & 1 & Agreement \\
\hline Moodle cut expenses of assignments & 0.90054 & 3.8049 & .000 & 5.723 & 76.098 & 1 & High \\
Moodle improves students motor skills & 0.88345 & 3.6585 & .000 & 4.773 & 73.17 & 2 & High \\
$\begin{array}{l}\text { Moodle helps to identify the strength } \\
\text { and weakness areas in learners }\end{array}$ & 1.0865 & 3.3415 & .051 & 2.012 & 66.83 & 4 & High \\
$\begin{array}{l}\text { Moodle enhances the effectiveness of } \\
\text { teaching }\end{array}$ & 0.99939 & 3.4146 & .011 & 2.657 & 68.292 & 3 & High \\
Total & & & & & & & High \\
\hline
\end{tabular}

The results of Table (5) indicate that the level of attitudes of faculty members towards the use Moodle in the teaching learning processes on the improvement of the evaluation process was at an average of 3.5549 and a 71.0798 percent. The results showed that the highest order of the first paragraph, the average level of the tasks assigned by the students was 3.8049 and a 76,098 percent. The level of significance of this paragraph is 0.000 . This value is less than the specified level of $\alpha=0.05$, while the lowest in the order was the third paragraph To recognize weakness and strength of students with a mean 3.3415 and 66.83 percent, with a significance of 0.051 level ,and this value is higher than the level of significance of the specified hypothesis $\alpha=0.05$.

Table 6. Mean, Standard Deviations, Percents and T Value of the Sample Scores on the Field of Effective Communication Process

\begin{tabular}{|c|c|c|c|c|c|c|c|}
\hline Item & Mean & SD & & $\mathrm{T}$ & Sig & $\mathrm{N}$ & Agreement Degree \\
\hline $\begin{array}{l}\text { Moodle helps to build effective } \\
\text { communication with students }\end{array}$ & 3.5854 & 0.86532 & 71.708 & 4.332 & .000 & 1 & High \\
\hline $\begin{array}{l}\text { Moodle helps students to } \\
\text { communicate with each other }\end{array}$ & 3.3659 & 0.94223 & 67.318 & 2.486 & .017 & 2 & High \\
\hline Total & 3.4756 & 0.67037 & 69.512 & 4.543 & .000 & & High \\
\hline
\end{tabular}

The results of Table (6) indicate that the attitudes of faculty memberstowards the use of Moodelin teaching learning processes on effective communication process came at an average of 3.4756 and 69.512 percent. The results showed that the highest order of the first paragraph, Moodle helps to build effective communication with students with 3.5854 average and 71.708 percent. The level of significance calculated on this paragraph is 0.000 and this value is 
less than the specified level of $\alpha=0.05$, while the lowest in the order was the second paragraph (Effective discussion among students themselves) with a mean of 3.3659 with 67.318 percent. This paragraph is a significant function because the level of significance calculated on this paragraph is 0.017 and this value is less than the level of significance specified by the hypothesis $\alpha=0.05$

Table 7. Mean, Standard Deviations, Percents and T Value of the Sample Scores on the Field Moodle Challenges

\begin{tabular}{|c|c|c|c|c|c|c|c|}
\hline Field & Mean & SD & $\mathrm{RP}$ & $\mathrm{T}$ value & $\mathrm{P}$ & Order & Agreement \\
\hline I used many tools in Moodle & 3.5854 & 0.83593 & 71.708 & 4.484 & .000 & 3 & High \\
\hline Traditional Methods are better than moodle & 3.6341 & 1.13481 & 72.682 & 3.578 & .001 & 2 & High \\
\hline Internet access for lecturer & 3.8293 & 0.91931 & 76.586 & 5.776 & .000 & 1 & High \\
\hline $\begin{array}{l}\text { Moodle is slowing the teaching process because } \\
\text { of technical problems }\end{array}$ & 3.4634 & 1.02707 & 69.268 & 2.889 & .006 & 4 & High \\
\hline Technicians deal effectively with Moodle issues & 3.3659 & 0.91532 & 67.318 & 2.559 & .014 & 6 & High \\
\hline PTUK offers training sessions for instructors & 3.3659 & 0.91532 & 67.318 & 2.559 & .014 & 6 & High \\
\hline $\begin{array}{l}\text { PTUK offers a proper technical assistance for } \\
\text { moodle }\end{array}$ & 3.439 & 1.11912 & 68.78 & 2.512 & .016 & 5 & High \\
\hline Total & 3.5261 & 0.55369 & 70.522 & 6.084 & .000 & & High \\
\hline
\end{tabular}

The results of Table (7) indicate that attitudes of faculty members towards the use of Moodle in the teaching learning processes on the field of challenges of Moodle came at an average of 3.5261 and a 70.522 percent. The results also showed that the highest ranking of the third paragraph (Internet access service) came with an average of 3.8293 and 76.586 percent. The level of significance calculated on this paragraph is 0.000 and this value is less than the specified level $\alpha=0.05$, while the lowest value was the fifth paragraph, technicians resolve Moodle issues effectively (with an average of 3.3659 , a 67.318 percent as well as a sixth category). The university offers a proper technical center with a mean of 3.3659 and 67.318 percent. The level of significance calculated on these two paragraphs is less than the significance level specified by the hypothesis $\alpha=0.05$

To answer the second question of the study which is: Is there any statistically significant difference between faculty members' attitudes which can be attributed to academic degree, gender, years of experience, age, college classification, no. of classes being taught by Moodle, and no. training sessions. To answer this question one way ANOVA was calculated. Results above have shown that there is a difference in means and standard deviations. Table (8) verify if there is a significant difference by ANOVA test.

Table 8. One way ANOVA: Academic Degree

\begin{tabular}{|c|c|c|c|c|c|c|}
\hline Variable & Group & $\mathrm{DF}$ & Mean of square & $\mathrm{SD}$ & $\mathrm{F}$ & Sig \\
\hline \multirow{2}{*}{$\begin{array}{l}\text { Facilitating and } \\
\text { organizing Teaching }\end{array}$} & Between Groups & 2 & .574 & .287 & \multirow{2}{*}{1.178} & \multirow{2}{*}{.319} \\
\hline & Within Groups & 38 & 9.255 & .244 & & \\
\hline Learning processes & Total & 40 & 9.828 & & \multirow{4}{*}{2.239} & \multirow{4}{*}{.120} \\
\hline \multirow{3}{*}{$\begin{array}{l}\text { Teaching methods } \\
\text { improvement }\end{array}$} & Between Groups & 2 & 1.918 & .959 & & \\
\hline & Within Groups & 38 & 16.274 & .428 & & \\
\hline & Total & 40 & 18.191 & & & \\
\hline \multirow{3}{*}{$\begin{array}{l}\text { Assessment process } \\
\text { improvement }\end{array}$} & Between Groups & 2 & .716 & .358 & \multirow{3}{*}{.703} & \multirow{3}{*}{.501} \\
\hline & Within Groups & 38 & 19.348 & .509 & & \\
\hline & Total & 40 & 20.064 & & & \\
\hline \multirow{3}{*}{$\begin{array}{l}\text { Communication process } \\
\text { improvement }\end{array}$} & Between Groups & 2 & 1.638 & .819 & \multirow{3}{*}{1.905} & \multirow{3}{*}{.163} \\
\hline & Within Groups & 38 & 16.338 & .430 & & \\
\hline & Total & 40 & 17.976 & & & \\
\hline \multirow{3}{*}{ Moodle usage challenges } & Between Groups & 2 & .954 & .477 & \multirow{3}{*}{1.603} & \multirow{3}{*}{.215} \\
\hline & Within Groups & 38 & 11.308 & .298 & & \\
\hline & Total & 40 & 12.263 & & & \\
\hline \multirow{3}{*}{ Total } & Between Groups & 2 & .993 & .496 & \multirow{3}{*}{2.380} & \multirow{3}{*}{.106} \\
\hline & Within Groups & 38 & 7.925 & .209 & & \\
\hline & Total & 40 & 8.917 & & & \\
\hline
\end{tabular}


Table (8) showed that there is no statistically significant differences due to academic degree because $\alpha>0.005$. To check other variables like, T-value has been calculated. In Table (9)

Table 9. T-test

\begin{tabular}{|c|c|c|c|c|c|c|}
\hline \multirow[t]{2}{*}{ Variable } & \multicolumn{2}{|c|}{$21=\mathrm{F}$} & \multicolumn{2}{|c|}{$20=\mathrm{M}$} & \multirow[t]{2}{*}{$\mathrm{T}$} & \multirow[t]{2}{*}{$\alpha$} \\
\hline & Mean & SD & Mean & SD & & \\
\hline $\begin{array}{l}\text { Facilitating and organizing of } \\
\text { educational learning process }\end{array}$ & 3.5584 & .51127 & 3.5823 & .49175 & -.152 & .880 \\
\hline Teaching methods improvement & 3.4558 & .64463 & 3.4119 & .72040 & .206 & .838 \\
\hline Assessment process improvement & 3.7500 & .60725 & 3.3500 & .76261 & 1.863 & .070 \\
\hline Communication process & 3.6667 & .73030 & 3.2750 & .54952 & 1.933 & .061 \\
\hline Moodle usage challenges & 3.6531 & .61041 & 3.3929 & .46551 & 1.529 & .134 \\
\hline Total construct & 3.6168 & .46921 & 3.4024 & .46132 & 1.474 & .148 \\
\hline
\end{tabular}

Table (9) shows that there are no statistically significance differences between instructors attitudes due to gender since $\alpha>0.05$

Another variable which is years of experiences of faculty members was also being investigated. Results in table (10) have shown that there are differences in means, so to support this hypothesis ANOVA test have been used.

Table 10. ANOVA Test

\begin{tabular}{|c|c|c|c|c|c|c|}
\hline Variable & & $\mathrm{F}$ & $\sum \mathrm{SD} 2$ & SD Average & $\mathrm{F}$ & $\alpha$ \\
\hline \multirow{3}{*}{$\begin{array}{l}\text { Facilitating and organizing } \\
\text { of teaching earning } \\
\text { processes }\end{array}$} & Between Groups & 2 & .758 & .379 & \multirow{2}{*}{1.588} & \multirow{2}{*}{.218} \\
\hline & Within Groups & 38 & 9.070 & .239 & & \\
\hline & Total & 40 & 9.828 & & \multirow{4}{*}{.891} & \multirow{4}{*}{.419} \\
\hline \multirow{3}{*}{$\begin{array}{l}\text { Teaching methods } \\
\text { improvement }\end{array}$} & Between Groups & 2 & .815 & .408 & & \\
\hline & Within Groups & 38 & 17.376 & .457 & & \\
\hline & Total & 40 & 18.191 & & & \\
\hline \multirow{3}{*}{$\begin{array}{l}\text { Assessment process } \\
\text { improvement }\end{array}$} & Between Groups & 2 & 1.867 & .934 & \multirow{3}{*}{1.950} & \multirow{3}{*}{.156} \\
\hline & Within Groups & 38 & 18.197 & .479 & & \\
\hline & Total & 40 & 20.064 & & & \\
\hline \multirow[t]{3}{*}{ Moodle usage challenges } & Between Groups & 2 & 2.214 & 1.107 & \multirow{3}{*}{2.668} & \multirow{3}{*}{.082} \\
\hline & Within Groups & 38 & 15.762 & .415 & & \\
\hline & Total & 40 & 17.976 & & & \\
\hline \multirow{3}{*}{$\begin{array}{l}\text { Communication } \\
\text { process }\end{array}$} & Between Groups & 2 & .205 & .102 & \multirow{3}{*}{.322} & \multirow{3}{*}{.726} \\
\hline & Within Groups & 38 & 12.058 & .317 & & \\
\hline & Total & 40 & 12.263 & & & \\
\hline \multirow[t]{3}{*}{ Total } & Between Groups & 2 & .971 & .485 & & \\
\hline & Within Groups & 38 & 7.947 & .209 & 2.321 & .112 \\
\hline & Total & 40 & 8.917 & & & \\
\hline
\end{tabular}

It was shown by table (10) that there are no statistically significant differences between instructors attitudes toward Moodle at PTUK and years of experience.

It was found the there are no statistically significant differences between teachers attitudes toward teaching and learning process and age PTUK. Results in table (11) have shown that there are differences in Means, so to support this hypothesis ANOVA test have been used. 
Table 11. ANOVA Test: Age

\begin{tabular}{|c|c|c|c|c|c|c|}
\hline Variable & & $\mathrm{F}$ & $\sum \mathrm{SD} 2$ & $\mathrm{SD}$ & $\mathrm{F}$ & $\alpha$ \\
\hline \multirow{2}{*}{$\begin{array}{l}\text { Facilitating and } \\
\text { organizing Teaching }\end{array}$} & Between Groups & 2 & .284 & .142 & \multirow{2}{*}{.566} & \multirow{2}{*}{.572} \\
\hline & Within Groups & 38 & 9.544 & .251 & & \\
\hline Learning processes & Total & 40 & 9.828 & & & \\
\hline \multirow{3}{*}{$\begin{array}{l}\text { Teaching methods } \\
\text { improvement }\end{array}$} & Between Groups & 2 & .922 & .461 & \multirow{3}{*}{1.015} & \multirow{3}{*}{.372} \\
\hline & Within Groups & 38 & 17.269 & .454 & & \\
\hline & Total & 40 & 18.191 & & & \\
\hline \multirow{3}{*}{$\begin{array}{l}\text { Assessment process } \\
\text { improvement }\end{array}$} & Between Groups & 2 & .207 & .103 & \multirow{3}{*}{.198} & \multirow{3}{*}{.821} \\
\hline & Within Groups & 38 & 19.857 & .523 & & \\
\hline & Total & 40 & 20.064 & & & \\
\hline \multirow{3}{*}{$\begin{array}{l}\text { Communication } \\
\text { process improvement }\end{array}$} & Between Groups & 2 & 1.190 & .595 & \multirow{3}{*}{1.347} & \multirow{3}{*}{.272} \\
\hline & Within Groups & 38 & 16.786 & .442 & & \\
\hline & Total & 40 & 17.976 & & & \\
\hline \multirow{3}{*}{$\begin{array}{l}\text { Moodle usage } \\
\text { challenges }\end{array}$} & Between Groups & 2 & .403 & .202 & \multirow{3}{*}{.646} & \multirow{3}{*}{.530} \\
\hline & Within Groups & 38 & 11.860 & .312 & & \\
\hline & Total & 40 & 12.263 & & & \\
\hline \multirow{3}{*}{ Total } & Between Groups & 2 & .482 & .241 & \multirow{3}{*}{1.085} & \multirow{3}{*}{.348} \\
\hline & Within Groups & 38 & 8.436 & .222 & & \\
\hline & Total & 40 & 8.917 & & & \\
\hline
\end{tabular}

There are no statistically significant differences between teacher's attitudes toward teaching and learning process and faculty at PTUK due to college specification. Results in table (12) have shown that there are no differences in Means, so to support this hypothesis a $\mathrm{T}$ test have been used.

Table 12. T-test

\begin{tabular}{|c|c|c|c|c|c|c|}
\hline \multirow[t]{2}{*}{ Variable } & \multicolumn{2}{|c|}{ Science $\mathrm{N}=32$} & \multicolumn{2}{|c|}{ Humanities $\mathrm{N}=9$} & \multirow[t]{2}{*}{$\mathrm{T}$} & \multirow[t]{2}{*}{$\alpha$} \\
\hline & Mean & SD & Mean & SD & & \\
\hline $\begin{array}{l}\text { Facilitating and organizing } \\
\text { Teaching Learning processes }\end{array}$ & 3.5685 & .50883 & 3.5758 & .47456 & -.038 & .969 \\
\hline Enhancing teaching methods & 3.4583 & .64455 & 3.3492 & .80847 & .424 & .674 \\
\hline Improving assessment process & 3.5781 & .73627 & 3.4722 & .63053 & .392 & .697 \\
\hline \multirow[t]{2}{*}{ Teaching methods improvement } & 3.4688 & .65915 & 3.5000 & .75000 & -.122 & .904 \\
\hline & 3.5000 & .55979 & 3.6190 & .55328 & -.565 & .575 \\
\hline Total & 3.5147 & .47296 & 3.5032 & .49776 & .064 & .950 \\
\hline
\end{tabular}

The previous table shows that there are no statistically significant differences among faculty members PTUK in facilitating and organizing the teaching learning processes due to college specification. In other words there are no differences in their attitudes due to college specification.

There are no statistically significant differences among faculty at PTUK due to no. of course being taught. A NOVA test has been done shown in table (13). 
Table 13. ANOVA Test: No. of Courses Being Taught by Moodle

\begin{tabular}{|c|c|c|c|c|c|c|}
\hline Variable & & $\mathrm{F}$ & $\sum \mathrm{SD}$ & SD & $\mathrm{F}$ & $\alpha$ \\
\hline \multirow{4}{*}{$\begin{array}{l}\text { Facilitating and } \\
\text { organizing Teaching } \\
\text { Learning processes }\end{array}$} & & 2 & .574 & .287 & \multirow{2}{*}{1.178} & \multirow{2}{*}{.319} \\
\hline & Between Groups & 38 & 9.255 & .244 & & \\
\hline & Within Groups & 40 & 9.828 & & \multirow{3}{*}{2.239} & \multirow{3}{*}{.120} \\
\hline & Total & 2 & 1.918 & .959 & & \\
\hline \multirow{2}{*}{$\begin{array}{l}\text { Teaching methods } \\
\text { improvement }\end{array}$} & Between Groups & 38 & 16.274 & .428 & & \\
\hline & Within Groups & 40 & 18.191 & & \multirow{4}{*}{.703} & \multirow{4}{*}{.501} \\
\hline \multirow{3}{*}{$\begin{array}{l}\text { Assessment process } \\
\text { improvement }\end{array}$} & Total & 2 & .716 & .358 & & \\
\hline & Between Groups & 38 & 19.348 & .509 & & \\
\hline & Within Groups & 40 & 20.064 & & & \\
\hline \multirow{3}{*}{$\begin{array}{l}\text { Communication process } \\
\text { improvement }\end{array}$} & Total & 2 & 1.638 & .819 & \multirow{2}{*}{1.905} & \multirow{2}{*}{.163} \\
\hline & Between Groups & 38 & 16.338 & .430 & & \\
\hline & Within Groups & 40 & 17.976 & & \multirow{4}{*}{1.603} & \multirow{4}{*}{.215} \\
\hline \multirow{4}{*}{$\begin{array}{l}\text { Moodle usage } \\
\text { challenges }\end{array}$} & Total & 2 & .954 & .477 & & \\
\hline & Between Groups & 38 & 11.308 & .298 & & \\
\hline & Within Groups & 40 & 12.263 & & & \\
\hline & Total & 2 & .993 & .496 & \multirow{3}{*}{2.380} & \multirow{3}{*}{.106} \\
\hline \multirow{2}{*}{ Total } & Between Groups & 38 & 7.925 & .209 & & \\
\hline & Within Groups & 40 & 8.917 & .287 & & \\
\hline
\end{tabular}

Table (14) shows that there are no statistically significant differences among faculty members at PTUK due to no. of training sessions.

Table 14. ANOVA: Illustrates the Differences in Attitudes According to No. of Training Sessions

\begin{tabular}{|c|c|c|c|c|c|c|}
\hline Variable & & $\mathrm{F}$ & $\sum \mathrm{SD} 2$ & SD & $\mathrm{F}$ & $\alpha$ \\
\hline \multirow{2}{*}{$\begin{array}{l}\text { Facilitating and } \\
\text { organizing Teaching }\end{array}$} & Between Groups & 2 & .980 & .490 & \multirow{2}{*}{2.104} & \multirow{2}{*}{.136} \\
\hline & Within Groups & 38 & 8.848 & .233 & & \\
\hline Learning processes & Total & 40 & 9.828 & & \multirow{4}{*}{.916} & \multirow{4}{*}{.409} \\
\hline \multirow{3}{*}{$\begin{array}{l}\text { Teaching methods } \\
\text { improvement }\end{array}$} & Between Groups & 2 & .836 & .418 & & \\
\hline & Within Groups & 38 & 17.355 & .457 & & \\
\hline & Total & 40 & 18.191 & & & \\
\hline \multirow{3}{*}{$\begin{array}{l}\text { Assessment process } \\
\text { improvement }\end{array}$} & Between Groups & 2 & 2.339 & 1.169 & \multirow{3}{*}{2.507} & \multirow{3}{*}{.095} \\
\hline & Within Groups & 38 & 17.725 & .466 & & \\
\hline & Total & 40 & 20.064 & & & \\
\hline \multirow{3}{*}{$\begin{array}{l}\text { Communication } \\
\text { process improvement }\end{array}$} & Between Groups & 2 & 4.630 & 2.315 & \multirow{3}{*}{6.592} & \multirow{3}{*}{.003} \\
\hline & Within Groups & 38 & 13.345 & .351 & & \\
\hline & Total & 40 & 17.976 & & & \\
\hline \multirow{3}{*}{$\begin{array}{l}\text { Moodle usage } \\
\text { challenges }\end{array}$} & Between Groups & 2 & 1.458 & .729 & \multirow{3}{*}{2.563} & \multirow{3}{*}{.090} \\
\hline & Within Groups & 38 & 10.805 & .284 & & \\
\hline & Total & 40 & 12.263 & & & \\
\hline \multirow{3}{*}{ Total } & Between Groups & 2 & 1.757 & .879 & \multirow{3}{*}{4.662} & \multirow{3}{*}{.015} \\
\hline & Within Groups & 38 & 7.160 & .188 & & \\
\hline & Total & 40 & 8.917 & & & \\
\hline
\end{tabular}

From the above table, it appears that there are no differences of statistical significance level $(0.05)$ in the attitudes of faculty members towards using Moodle due to the no. of training sessions being offered at PTUK in four categories: facilitating and organizing teaching learning processes, improving teaching methods, improving assessment process, and challenges of using Moodle. On the other hand, there is a difference in the effective communication due to no. of training sessions. 
Table 15. Differences in Attitudes According to No. of Training Sessions Attended

\begin{tabular}{lll}
\hline Communication process improvement & Means Differences & $\alpha$ \\
\hline Not attended any session & $-.95968^{*}$ & .004 \\
Attended more than a session & $-.62634^{*}$ & .023 \\
Total & $-.59874^{*}$ & .013 \\
\hline
\end{tabular}

From the above table, it appears that there are differences of statistical significance level $(0.05)$ in the attitudes of faculty members towards using Moodle due to no. of training sessions that university offer, $\alpha<0.05$

\section{Discussion}

This study aimed to examine the attitudes of faculty members towards Moodle at PTUK in Science and Humanities colleges. Based on the results discussed previously, it is clear that faculty members at PTUK have positive attitudes towards using Moodle, and that there are no differences in the attitudes due to, age, gender, academic degree, years of experience, college classification, no. course being taught by Moodle, no. of training sessions has been offered. There are differences in attitudes toward the efficiency of the communications process due to the no. of training sessions had been attended at PTUK. These results indicate that the faculty members at PTUK using Moodle have sufficient understandings of the importance of virtual learning platforms and using ICT in teaching; which represents a very encouraging situation in the e-learning field at PTUK.

These results are similar with Badia et al. (2018) that showed factors like educational ICT training and Internet access are important keys in teacher's perceptions of digital technology. Also, more than three -quarter percent of the lectures had positive attitudes toward Moodle tools like links, videos, audio files.

Breen \& Paul (2018) also recommended Virtual learning environments for teachers and described it as "this had been transformed to a vehicle for learning that was still largely driven by the teachers" p. 143.

\section{Recommendations and Proposals}

Based on the results of this study, the researcher proposes to PTUK the followings: -

- Holding training courses for faculty members in PTUK, so that they are trained in how to use moodle and put more emphasis on how to implement e- learning.

- Offer Internet access and increase bandwidth for faculty members and students.

- Training students on learning skills, computer skills and how to use the Internet in learning and searching toreinforce self-learning process.

- Enrichment of faculty training programs in Palestinians universities with courses related to e-learning, computer use and the Internet in teaching.

\section{Suggested Research}

Researcher suggests future research with emphasis on Moodle efficiency in improving teaching methods and student learning skills. Also, student attitudes toward Moodle at different universities.

\section{References}

Badia, A., Martín, D., \& Gómez, M. (2018). Teachers' Perceptions of the Use of Moodle Activities and Their Learning Impact in Secondary Education. Technology, Knowledge and Learning, 1-17. https://doi.org/10.1007/s10758-018-9354-3

Bates, A. W., \& Sangra, A. (2011). Managing technology in higher education: Strategies for transforming teaching and learning. John Wiley \& Sons, 51(2), 35-39.

Black, E. W., Beck, D., Dawson, K., Jinks, S., \& DiPietro, M. (2007). Considering implementation and use in the adoption of an LMS in online and blended learning environments. TechTrends, 51(2), 35-53. https://doi.org/10.1007/s11528-007-0024-x

Breen, Paual. (2018). Developing Educators for The Digital Age Book Subtitle: A Framework for Capturing Knowledge in Action. University of Westminster Press. https://doi.org/10.16997/book13 
Brown, M., Dehoney, J., \& Millichap, N. (2015). What's Next for the LMS. Educause Review, 50(4), 40-51.

Caliskan, S., \& Bicen, H. (2016). Determining the perceptions of teacher candidates on the effectiveness of MOODLE used in flipped education. Procedia Computer Science, 102, 654-658. https://doi.org/10.1016/j.procs.2016.09.457

Carvalho, A., Da Silva, A., \& Freitag, L. (2013). Accessibility in virtual Moodle learning environment: literature review. Journal of Nursing UFPE, 7(s), 969-976.

Carnell, B. S., \& Fung, D. (Eds). (2017). Developing the Higher Education Curriculum. UCL Press: London, UK.

Fadel, E. A., Elbilgahy, A. A., Ibrahim, I. A., \& Elmashad, H. A. M. (2019). Undergraduate Nursing Students' and Lecturers' Attitudes towards Modular Object Oriented Dynamic Learning Environment: A Quasi Experimental Study. American Journal of Nursing, 7(1), 24-30.

Franco, C. (2010). Moodle as an Alternative to Flexible Education, Revista EducaOnline, 1(1). Retrieved from: http://www.claudiofranco.com.br/textos/franco_educaonline_03.pdf

Hamed, S. (2019). Digital Education: A Conceptual and Theoretical View, Arabic Journal for Educational and Psychological Sciences, 7(7), 137-148.

Horton, W. (2011). E-learning by design. John Wiley \& Sons.

Inan, F. A., \& Lowther, D. L. (2010). Factors affecting technology integration in K-12 classrooms: a path model. Educational Technology Research and Development, 58(2), 137-154. https://doi.org/10.1007/s11423-009-9132-y

Jacobs, C., Wilson, M., \& Barker, C. (2015, December). Using the latest developments in mobile technology to improve students' engagement with assessment feedback. In 2015 International Conference on Interactive Mobile Communication Technologies and Learning (IMCL). IEEE. https://doi.org/10.1109/imctl.2015.7359569

Kvavik, R. B., \& Caruso, J. B. (2005). ECAR study of students and information technology: Convenience, connection, control, and learning. Boulder, CO: Educause Center for Applied Research. Retrieved Jan 23, 2019, from http://www.educause.edu/ir/library/pdf/ers0405/rs/ers0405w.pdf

Lane, L. M. (2009). Insidious pedagogy: How course management systems affect teaching. First Monday, 14(10), 5-10. https://doi.org/10.5210/fm.v14i10.2530

Martín-Blas, T., \& Serrano-Fernández, A. (2009). The role of new technologies in the learning process: Moodle as a teaching tool in Physics. Computers \& Education, 52(1), 35-44. https://doi.org/10.1016/j.compedu.2008.06.005

Masadeh, T. S. Y., \& Elfeky, A. I. M. (2016). The Effect of Mobile Learning on Students' Achievement and Conversational Skills. International Journal of higher education, 5(3), 20-31. https://doi.org/10.5430/ijhe.v5n3p20

Masadeh, T. S. Y., \& Elfeky, A. I. M. (2015). Efficacy of Open-Source Learning Management Systems in Developing the Teaching Skills of English Language Student Teachers. American Journal of Educational Research, 4(4), 329-337.

Moodle. (2019). Retrieved Jan. 15, 2019, from http:// moodle.org

Murugesan, R. (2012). Promising outcomes of an online course in research writing at a Rwandan University. European Science Editing, 38(3), 60-64.

Ngampornchai, A., \& Adams, J. (2016). Students' acceptance and readiness for E-learning in Northeastern Thailand. International Journal of Educational Technology in Higher Education, 13(1), 34-42. https://doi.org/10.1186/s41239-016-0034-x

Nordin, N., \& Ibrahim, S. (2012). Leveraging Open Source Software in the Education Management and Leadership Training. Turkish Online Journal of Educational Technology-TOJET, 11(3), 215-221.

Ozkan, S., \& Koseler, R. (2009). Multi-dimensional evaluation of e-learning systems in the higher education context: an empirical investigation of a computer literacy course. In Frontiers in Education Conference, 2009. FIE'09. 39th IEEE (pp. 1-6). IEEE. https://doi.org/10.1109/fie.2009.5350590

Pachler, N., \& Daley, C. (2011). Key issues in e-learning: Research and practice. A\&C Black.

Park, J. Y., \& Mills, K. A. (2014). Enhancing interdisciplinary learning with a learning management system. MERLOT Journal of Online Learning and Teaching, 10(2), 299-313. 
Perrotta, C. (2013). Do school-level factors influence the educational benefits of digital technology? A critical analysis of teachers' perceptions. British Journal of Educational Technology, 44(2), 314-327. https://doi.org/10.1111/j.1467-8535.2012.01304.x

Piotrowski, M. (2010). What is an e-learning platform? Learning management system technologies and software solutions for online teaching: tools and applications. IGI Global. https://doi.org/10.4018/978-1-61520-853-1.ch002

Sallam, N., \& Alzouebi, K. (2014). Teacher Perceptions of the Use of Moodle to Enhance the Quality of Teaching and Learning in a K-12 Private School in the United Arab Emirates. Journal of Teaching and Teacher Education, 2, 93-102. https://doi.org/10.12785/jtte/020202

Sanchez, R. A., \& A. D. Hueros. (2010). Motivational factors that influence the acceptance of Moodle using TAM. Computers in Human Behavior, 26(6), 1632-1640. https://doi.org/10.1016/j.chb.2010.06.011

Santos, L., Inan, F., \& Denton, B. (2012). Examining of Factors Impacting Student Satisfaction with a New Learning Management System. Turkish Online Journal of Distance Education (TOJDE), 13(3).

Tinmaz, H. (2012). Social networking websites as an innovative framework for connectivism. Contemporary Educational Technology, 3(3), 234-245.

William, H. R. (2015). Moodle: E-Learning Course Development (3rd ed.). Packt Publishing Ltd: Birmingham, UK. 